\title{
Nasopharyngeal Differentiated
} Carcinoma

National Cancer Institute

\section{Source}

National Cancer Institute. Nasopharyngeal Differentiated Carcinoma. NCI Thesaurus.

Code $C 54389$.

A nonkeratinizing nasopharyngeal carcinoma characterized by the presence of cells without prominent nucleoli, cellular stratification, and a lymphoplasmacytic infiltrate. 